\title{
TO THE QUESTION OF M. CHEKHOV'S METHODOLOGY IN THE CREATION OF CONTEMPORARY DRAMA FILM WORK
}

\author{
Iryna Gavran ${ }^{1 a}$, Valeriia Dombrovska ${ }^{2 a}$ \\ ${ }^{1}$ PhD in Pedagogic Sciences, Senior Lecturer at the Department \\ of Television Journalism and Acting; \\ e-mail: yarynka.77@gmail.com; ORCID: 0000-0002-6777-3038 \\ ${ }^{2}$ Assistant at the Department of the Television Journalism and Acting, Master Student of the Film \\ and Television Faculty; e-mail: dombrovskayavalery@gmail.com; ORCID: 0000-0002-8339-9699 \\ ${ }^{a}$ Kyiv National University of Culture and Arts, Kyiv, Ukraine
}

\section{Keywords:}

transformation;

actor;

action;

creativity;

image;

reincarnation;

technique

\begin{abstract}
The purpose of the study. The main theoretical and practical aspects relating to the actor's skill, as well as identifying the features of the actor's work on the role in the process of creating the character's image according to M. Chekhov's methodology in forming modern dramatic art have been determined. Research methodology consists in applying a systematic and analytical approach for defining the goals and strategies of scientific research, namely using special methods and techniques, which describe the essence and features of individual methodology of creative activities of famous masters of cinema and theatre Anton Chekhov. The scientific novelty consists in creating an image of the character in the modern dramatic cinematography based on M. Chekhov's professional technology within the given concept. Conclusions. According to the goal of the research, it has been found out that despite the opposite opinions regarding the education of an actor; almost all researchers of actor's art agree that any professional actor should have a technological base. It includes the use of a speech apparatus, a voice in a dramatic vocal, a body in flexible etudes and dances and other skills, namely analysis and study of the play, roles, creating an image, building an effective character line, determining the hero's overarching goal, finding the internal monologues, etc. In a scientific study, the actor's place in an audiovisual work has been found, and it has been determined that the actor is both the creator and tool of his art, the actions he performs, and the material for creating the character's image. Also in the course of the study, the creation of the hero's stage image in the play has been analyzed and characterized, and the actor's work on the role has been revealed.
\end{abstract}

For citation:

Gavran, I. and Dombrovska, V. (2019). To the Question of M. Chekhov's Methodology in the Creation of Contemporary Drama Film Work. Bulletin of Kyiv National University of Culture and Arts. Series in Audiovisual Arts and Production, 2(1), pp.8-14.

\section{Formulation of the problem}

Focusing in this research on film work, it is worth to mention that the theater and film have many common features of the work of the actor. Because M. Chekhov started his creative way from the theater, and then began acting in films. Therefore, 
the material of the actor's art is the action, which is the bearer of all that is an acting. Using live visual human action actor creates his characters (there is a reason they are called actors). Because these same actions actor invent in himself, it can be argued that the actor himself is a tool. Therefore, the actor is a creator and the tool of his art at the same time, as he does the action for creating his image.

Appropriate to say that the actor is not only material, he is also the creator. $\mathrm{He}$ is also the creator and the object of director's creation. Accordingly, the actor, as the creator is a real material for the director. Creative interaction between the director and the actor on the movie set is the basis of production method when creating a modern drama film. The actor learns all his life. It is a creative process, which is actor's lifelong and became more intensive because of independent work, the beginning of which is school. The creating of an artistic image through reincarnation is a goal, at which the whole process of creative work of the actor on the role is directed.

Creative individuality lies in the personality of the actor. The art of experience demands from the actor living embodiment of the human image, all its facets and veracity of the character transferring. It is important to play on the screen the life itself. The necessary component of creativity is the knowledge of life and the ability to summarize it by specific means of the art. Understanding and awareness of what is happening in life, analysis of reality are qualities that are inherent to the real actor. The most disturbing moments in the creativity of the young actor are the attention to vital phenomena, their aesthetic evaluation The actor's image is compelling and aesthetically valuable not by itself, but to the extent through which the main drama action develops, its its general content and ideological orientation turn out.

\section{Analysis of recent research and publications}

It is worthwhile to note that the value of difference systems K. Stanislavskyi and $M$. Chekhov - geniuses of the world theater also affects the basic material of actor's art, and not because they were unique on the talent of the actors, but because each of them left behind his own acting "school". Therefore, two the most famous books on the actor's art, created in the XX century: "The Actor's Work on himself" by Stanislavskyi and "About the Actor's Technique" by Chekhov. The technique, described in these two books are quite dissimilar in the theory and practice of the actor's art.

What is the most divergent opinions of these two great actors, directors and teachers? M. Chekhov considers that K. Stanislavsky too relies on personal experience and worldview of the artist when holds it in the scope of the proposed circumstances of the role. He also did not agree that the cognition of image began with the easiest of physical actions that allowed the actor to experience some of the truth of life. More dramatic distinctions in views can be seen, if you raise the issue of "affective memories", as M. Chekhov called them, or "emotional memory", as Stanislavskyi said. The word «memories" and "memory" have different shade of meaning: memory is more specific than memories, and memories are easier to intersect with the fantasy, thus Chekhov lacked it in K. Stanislavskyi system. According to M. Chekhov, an actor needs to forget about themselves and submit his character, who is surrounded 
by the relevant circumstances (1986, p.125), and K. Stanislavsky stated that an outside perspective at the image will lead to the demonstration of feelings, to replacement of experience. So, Chekhov called trust hot mysterious creative feelings, commonly called "inspiration", and K. Stanislavskyi did not advise to base on the whims of "inspiration", he preferred another to have in the hands a reliable means of managing them, and it was his "system".

In his criticism of the method of K. Stanislavski, M. Chekhov was not original. Similar objections ezpressed F. F. Komisarzhevskyi, E. B. Vakhtanhov, V. I. Nemyrovych-Danchenko. They blamed Stanislavskyi method in naturalism, oppression of creative imagination and fantasy, neglect of intuition. In the study it should be pointed out that K. Stanislavskyi system impresses with clear expectation, notably, not with inspiration, that depends on mood with which the actor stood up today, on events occurring in his life. However, it relies on a clear system, designed for excitement and recreation necessary feelings, the execution of which allows in any situation (in a bad mood, in a stressful situation, sickness) only due to actor's methods play the role from the start to the final.

The aim of the research is determining the main theoretical and practical aspects relating to the application of the methodology of M. Chekhov in the creation of modern drama film work, as well as identifying features of the actor over his role in the process of an character image creating.

\section{Presenting basic material}

On the diffi-cult path to the image, the main tool which must stir up an actor's feelings, to put in motion a chain of associations, to awaken the memory of the past and lead to the transformation is the development of the circumstances proposed. The real transformation is achieved by accumulating, precise selection of the proposed circumstances, mastering what the actor is naturally comes to the dialectic jump from personal actor's "I" to the image. The viewer knows the artist does not lose it from view, but at the same time recognizes and newcreated image.

It should be noted that the actor's palette is the whole man. Hands, eyes, ears and heart of the actor is at the same time a target and an instrument of his work. With such approach the art becomes a lifework; actor gradually expands his knowledge about himself not only during rehearsals, but also during the performance - a huge exclamation in his monologue.

In our study we should say that an actor should allow the image to penetrate his soul. At the beginning, everything resists this invasion, but the actor with stubborn hard work takes on a range of technical skills that allow him to control his body and psyche and suppress the resistance. Role "self-resistanse" is connected with self-revelation: the actor willingly shows his true face, realizing that it is impossible to understand the secrets of the role, not abandoning the protective covers, not revealing the secrets of his "I". Thus, the performance of the role becomes a sacrifice, and the actor publicly brings the sacrifice of their "I", which most people prefer to hide. People are divided into laypeople who make necessary in the life business, and those who burden for the sake of laypeople. A priest conducts the ceremony not only for myself but also for others. Practice shows that a real birth 
onstage image is always long and very complicated process. Process, during which the actor gradually learns his hero, selects traits inherent his character, and then gets close to them, grow them in himself. In this process the actor's observation, imagination, his will, life experience, and a number of other qualities, that you already have to know, play very important role. Many things depends on the actor's attitude towards the life, as he perceives it, from their ideological views, moral beliefs. In any case, the creation of onstage image is a great, diligent and painstaking work. Besides it is the work not only in rehearsals (1984, p.96).

We should also note that the interrelated processes that take place almost all the time in parallel, namely the accumulation and selection of tools, as well as mastering the suggested circumstances, the knowledge of the role appears, without which it is impossible to achieve the desired result - the reincarnation of the actor into the image. Therefore, the path of comprehensive development, and not the declaration of offered by life circumstances of literary character, on the basis of which the actor creates his image, is the right way of actor's movement to the image. The work of M. Chekhov "About Actor's Technique" is very important regarding this. Nothing should go past the attention of actor. Like a good detective, he is obliged to go into the private, public, and political life of the persons of all times and all peoples. They are the requirements of the profession. Scientific knowledge of literature, history as well as political issues have to come from the life itself that is to be associated with the practical requirements of the actor's skills, our art and the stage. As M. Chekhov noted: "If you take a camera and walk out on the street, you might find scenes worth to be shot, even if you do not put yourself such a goal. The actors should act in such a way without any camera too. Wandering the streets, pay your attention to the nuances of human behavior" (1986, p. 183).

Model of the image is disigned in the imagination; it is dynamic. In the course of work it is developed, surrounded by findings, is complemented by more new colors. As it has been already noted, an important feature of the actor's work lies in the fact that the fruits of his fantasies are realized in action, acquiring concreteness in the expressive movements. The actor all the time embodies findings, and a passage, which is played true in its turn, gives impetus to imagination. Image created by imagination, is perceived by the actor aside and lives like regardless of its creator.

According to M. Chekhov "You should not think that the images will be in front of you completed and finished. They will require a lot of time changing and improving in order to reach the desired degree of expressiveness. You must learn to wait patiently. But waiting, does it mean to be in passive contemplation of the images? No, It, does not. Despite the ability of the images live their separate lives, your essence is the condition of their development" (1986, p.152). In order to understand the character, $\mathrm{M}$. Chekhov believes,it is necessary to ask him questions, but so that the inner eye to see how the image plays the response. As M. Chekhov stated: "Actor must be able to do everything. Not only the face, eyes and hands must be expressive in him, but also the back, shoulder, calves, even ankles. He should sneak in hidden and secret world of his hero soul. Nevertheless, he must give the spectacular and expressive flesh of the image. Both of these processes 
is the implementation of the internal and external image understanding-inseparable, interdependent need each other. No matter in what sequence they occur. Often they are at the same time. Only in their balance target harmony of image is achievable when the actor and the director together toil over the task on the rehearsals." (1986, p.93).

Undoubtedly, the actor should pay not less time the mental and emotional developing than the development of body and voice. Many actors have good emotionality from nature. But if it is not supported by knowledge and impressions, it is an exploitation of emotion, and acting is more like a fit of histeria. However, this acting may seem quite sincere for an unsophisticated viewer, but experienced actors know that the ability to "squeeze a tear" has no relation to the true feeling. After all, feelings do not arise by themselves, thrir appearance depends on those experiences, events, interests, in which a person lives in the present. While processing these experiences, events and interests is a function of thought. M. Chekhov wrote: "We are not going to talk about feelings - it cannot be raped it should be cherished.It can not be called by force. It will come itself depending on the proper execution of the bodily line of action" (1986, p.181), because an action line is built in the period of intellectual work on role. Thus, acting training is primarily the intelligence training. It is known that the imagination for every person who is engaged in the arts is very essential. There is no an actor, an artist, a musician or a writer without imagination. As V.I. Nemirovich-Danchenko noted: "The Acting profession is unique. It really stands out from all other human ocupations. Its uniqueness lies in the fact that all the actor's activities goes not in real but in fictional world" (1952, p.105). But the imagination is like the feeling: it is not in itself, it needs food. Moreover, intelligence delivers that food, accumulating in the memory of the impression of a different sort. Imagination is not be able to work without the intellectual "Bank experience". And this "Bank" often can only be created through targeted efforts, i.e. by means of training. The only units of induviduals have the happy ability to detect all around automatically, soak up knowledge, and memorize events in all details. But even for such capable people it is hard to imagine what they have never seen in their life. Because actors transform into different people. Do not forget that we, the actors, have to convey the life of a human spirit, the role of all eras, peoples. As M. A. Chekhov wrote: "Learn to look at life. Looking at life for an actor is a great art. You must now learn to 'devour knowledge"' (1984, p.182).

\section{Conclusions}

Summing up the above mentioned, it should be noted that despite the opposite opinions on education actor, almost all researchers of the actor's art converge in one - any professional actor should have a technological base, which includes owning a linguistic device, possession of voice in dramatic vocals, possession of a body in a flexible epodes and dances and other skills: reviewing and analysis of the play and the role, creating the image, designing an efficient line of character definition overarching goal of the hero, finding the exact internal monologues etc.

The work revealed the actor's place in drama film. It was determined that the actor is a creator and an instrument of his art at the same time and the actions done by 
him are the material for creating an image. It was highlighted the specifics of the actor's work over a role in the process of creating the character's image. It was also analyzed and characterized the process of hero image creating in the audiovisual work. The action is the main material in the art of the actor, and it is a specific feature of the actor's art. The foundation of a shooting method on a movie set is a creative interaction between a director and an actor. It is pointed out that one of the major problems in the preparation of a modern theater and cinema actor in Ukrainian relevant special secondary and higher educational establishments are blind amateur imitation of K. Stanislavskyi's rehearsal techniques fixed roughly only on paper; the actual neglect of the artistic heritage of M. Chekhov, O. Tairov, Ye. Grotovskyi and others.

\section{REFERENCES}

Avrov, D.N., 1985. Spektakl i zritel:(Kak smotret i otcenivat spektakl). [Performance and the viewer: (How to watch and to evaluate the performance)]. Moscow: Prosveshchenie.

Ivanova, V.V. ed., 1986. Akter. Personazh. Rol. Obraz [Actor. Character. Role. Form]. Leningrad: Leningrad State Institute of Theater, Music and Cinematography.

Livnev, D. ed., 1984. Masterstvo aktera: Teoriia i Praktika [Actor's Mastery: Theory and Practice]. Moscow: Iskusstvo.

Nemirovich-Danchenko, V., 1952. Stati, rechi, pisma, besedy [Articles, speeches, letters, conversations]. Moscow: Iskusstvo.

Nemirovskii, A., 1976. Plasticheskaia vyrazitelnost aktera [Flaxible actor's expressiveness]. Moscow: Iskusstvo.

Kozlianinovoi, I.P. ed., 1968. Problemy stcenicheskoi rechi [Problems of stage speech]. Moscow: Prosveshchenie.

Stanislavskii, K.S., 2006. Rabota aktera nad soboi [Actor's work on himself]. Moscow: Artist. Rezhisser. Teatr.

Stanislavskii, K.S., 1960. Sobranie sochinenii [Collected Works]. In: Vol. 7. Moscow: Iskusstvo. Stromov, lu.A., 1975. Put aktera $k$ tvorcheskomu perevoploshcheniiu [The path of an actor to creative reincarnation]. Moscow: Prosveshchenie.

Chekhov, M.A., 1986. Literaturnoe nasledieiu [Literary heritage]. In: Vol. 2: Memoirs. Letters Moscow: Iskusstvo.

\section{ДО ПИТАННЯ МЕТОДОЛОГІЇ М. ЧЕХОВА У СТВОРЕННІ СУЧАСНОГО ДРАМАТУРГІЧНОГО КІНОТВОРУ}

\section{Ірина Гавран ${ }^{1 a}$, Валерія Домбровська $^{2 a}$}

\footnotetext{
${ }^{1}$ кандидат педагогічних наук, старший викладач кафедри тележурналістики та майстерності актора; e-mail: yarynka.77@gmail.com; ORCID: 0000-0002-6777-3038

2 асистент кафедри тележурналістики та майстерності актора, магістрант факультету кіно і телебачення; e-mail: dombrovskayavalery@gmail.com; ORCID: 0000-0002-8339-9699

а Київський національний університет культури і мистецтв, Київ, Україна
}

\section{Анотація}

Мета дослідження - визначення головних теоретичних і практичних аспектів, які стосуються питання застосування методології М. Чехова у створенні сучасного драматургічного кінотвору, а також виявлення особливостей роботи актора над роллю в процесі створення образу персонажа. 
Методологія дослідження передбачає звернення до системно-аналітичного підходу щодо визначення цілей та стратегій наукового дослідження, а саме за допомогою спеціальних методів та засобів, схарактеризовано сутність і особливості використання власної методології у творчій діяльності відомого майстра кіно і театру М. Чехова. Наукова новизна дослідження полягає у тому, щоб на базі професійної техніки М. Чехова у межах заданої концепції створити образ персонажу в сучасному драматургічному кінотворі. Висновки. Відповідно до поставленої мети дослідження з'ясовано, що попри протилежність думок щодо виховання актора, майже всі дослідники акторського мистецтва сходяться в одному: будь-який професійний актор повинен мати технологічну базу. До неї входить володіння мовним апаратом, володіння голосом у драматичному вокалі, володіння тілом у пластичних етюдах і танцем та інші вміння, а саме: аналіз і розбір ролі, створення образу, побудова дієвої лінії персонажа, визначення надмети героя, пошук точних внутрішніх монологів та інше. У проведеному науковому дослідженні виявлено місце актора в аудіовізуальному творі та визначено, що актор водночас є і творцем, і інструментом свого мистецтва, і виконувані ним дії є матеріалом для створення образу персонажа. Також у ході дослідження було проаналізовано та схарактеризовано створення образу героя в драматургічному кінотворі та розкрито особливості роботи актора над роллю.

Ключові слова: трансформація; актор; дія; творчість; образ; перевтілення; техніка

\title{
К ВОПРОСУ МЕТОДОЛОГИИ М. ЧЕХОВА В СОЗДАНИИ СОВРЕМЕННОГО ДРАМАТУРГИЧЕСКОГО КИНОПРОИЗВЕДЕНИЯ
}

\author{
Ирина Гавран ${ }^{1 a}$, Валерия Домбровская ${ }^{2 a}$ \\ ${ }^{1}$ кандидат педагогических наук, старший преподаватель кафедры тележурналистики и актёрского \\ мастерства; e-mail: yarynka.77@gmail.com; ORCID: 0000-0002-6777-3038 \\ ${ }^{2}$ ассистент кафедры тележурналистики и актёрского мастерства, магистрант факультета \\ кино и телевидения; e-mail: dombrovskayavalery@gmail.com; ORCID: 0000-0002-8339-9699 \\ ${ }^{a}$ Киевский национальный университет культуры и искусств, Киев, Украина
}

\section{Аннотация}

Цель исследования - определение основных теоретических и практических аспектов, касающихся мастерства актёра, а также выявление особенностей работы актёра над ролью в процессе создания образа персонажа по методологии М. Чехова в создании современного драматургического кинопроизведения. Методология исследования заключается в применении системно-аналитического подхода к определению целей и стратегий научного исследования, а именно с помощью специальных методов и приёмов, охарактеризованы сущность и особенности использования собственной методологии в творческой деятельности известного мастера кино и театра М. Чехова. Научная новизна заключается в том, чтобы на базе профессиональной техники М. Чехова в пределах заданной концепции создать образ персонажа в современном драматургическом кинопроизведении. Выводы. Согласно поставленной цели исследования выяснено, что несмотря на противоположность мнений относительно воспитания актёра, почти все исследователи актёрского искусства сходятся в том, что любой профессиональный актёр должен иметь технологическую базу. В неё входит владение речевым аппаратом, владение голосом в драматическом вокале, владение телом в пластических этюдах и танцем и другие умения, а именно: анализ и разбор роли, создание образа, построение действенной линии персонажа, определение сверхцели героя, нахождение точных внутренних монологов и т.д. В проведённом научном исследовании обнаружено место актёра в аудиовизуальном произведении и определено, что актёр одновременно является и создателем, и инструментом своего искусства, и выполняемые им действия являются материалом для создания образа персонажа. Также в ходе исследования было проанализировано и охарактеризовано создание образа героя в драматургическом кинопроизведении и раскрыты особенности работы актёра над ролью.

Ключевые слова: трансформация; актёр; действие; творчество; образ; перевоплощение; техника 